\title{
Urban Fire Severity and Vegetation Dynamics in Southern California
}

\author{
Lauren E. H. Mathews and Alicia M. Kinoshita *D
}

check for updates

Citation: Mathews, L.E.H.; Kinoshita, A.M. Urban Fire Severity and Vegetation Dynamics in Southern California. Remote Sens. 2021, 13, 19. https:// dx.doi.org/10.3390/rs13010019

Received: 12 November 2020 Accepted: 17 December 2020 Published: 23 December 2020

Publisher's Note: MDPI stays neutral with regard to jurisdictional claims in published maps and institutional affiliations.

Copyright: () 2020 by the authors. Licensee MDPI, Basel, Switzerland. This article is an open access article distributed under the terms and conditions of the Creative Commons Attribution (CC BY) license (https: / / creativecommons.org/ licenses/by/4.0/).
Department of Civil, Construction \& Environmental Engineering, San Diego State University, San Diego, CA 92182-1326, USA; lmathews@sdsu.edu

* Correspondence: akinoshita@sdsu.edu

\begin{abstract}
A combination of satellite image indices and in-field observations was used to investigate the impact of fuel conditions, fire behavior, and vegetation regrowth patterns, altered by invasive riparian vegetation. Satellite image metrics, differenced normalized burn severity (dNBR) and differenced normalized difference vegetation index (dNDVI), were approximated for non-native, riparian, or upland vegetation for traditional timeframes (0-, 1-, and 3-years) after eleven urban fires across a spectrum of invasive vegetation cover. Larger burn severity and loss of green canopy (NDVI) was detected for riparian areas compared to the uplands. The presence of invasive vegetation affected the distribution of burn severity and canopy loss detected within each fire. Fires with native vegetation cover had a higher severity and resulted in larger immediate loss of canopy than fires with substantial amounts of non-native vegetation. The lower burn severity observed 1-3 years after the fires with non-native vegetation suggests a rapid regrowth of non-native grasses, resulting in a smaller measured canopy loss relative to native vegetation immediately after fire. This observed fire pattern favors the life cycle and perpetuation of many opportunistic grasses within urban riparian areas. This research builds upon our current knowledge of wildfire recovery processes and highlights the unique challenges of remotely assessing vegetation biophysical status within urban Mediterranean riverine systems.
\end{abstract}

Keywords: riparian; invasive vegetation; burn severity; canopy loss; wildfire

\section{Introduction}

Across the world, wildfires are increasing in frequency and magnitude under a changing climate and increased human interaction, which in turn impacts natural resources, infrastructure, and millions of people [1]. Continuous landscape conversion due to the expansion of the human population in southern California has fragmented chaparral ecosystems and encouraged urbanization to spread into the wildlands. This has increased the potential for ignition and damages to human communities and surrounding ecosystems [2,3].

Riparian environments serve as corridors that provide habitat connectivity for flora and fauna throughout wildland and urban riverine systems. These corridors starkly differ from the upland vegetation in species composition, functional type, canopy cover, and moisture content $[4,5]$. The immediate riparian zone surrounding Mediterranean riverine systems (Med-sys) is associated with different vegetation types with high relative humidity and cool temperatures, which can act as a barrier to fire spread. These riparian areas often exhibit the rapid recovery of pre-fire vegetation biomass in comparison to upland chaparral $[4,6]$. Hydrologic disturbances caused by urbanization, especially the increase of dry weather base-flow due to impermeable land cover ("urban drool"), significantly alter native riparian vegetation density and community structure [7]. Compounded by higher nutrient loads and heightened disturbance from more frequent flash floods, urban riparian environments encourage invasions and rapid settlements of opportunistic and invasive vegetation species [8-11]. 
Since 2002, the number of fires under $5 \mathrm{~km}^{2}$ in the urban riparian environment has increased in southern California [12]. This can be attributed to human ignition sources from transportation corridors, recreation, powerlines, and people experiencing homelessness $[2,13,14]$. Further, invasive plant infestations increase the density of vegetation biomass, which profoundly alters riverine hydrology and geomorphology and also impacts fire behavior and frequency within these systems [13-15]. The universal infestation of non-native vegetation throughout the stream and river systems of coastal California in conjunction with human ignition sources has arguably instituted a new regime of invasive grass-fire feedback cycles within the urban environment [14-16].

The impact of invasive species infestation on fire behavior, specifically in the urban environment, has not been previously documented. Studies indicate that as climate and other anthropogenic alterations, such as drought, human ignition sources, vegetation type conversion, and fuel accumulation, intensify, riparian environments in southern California are changing from flood-defined to fire-defined ecosystems $[10,15,17]$. However, further research is needed to describe the impact of invasive species on fire patterns and ecosystem recovery throughout the urban landscape, and to provide information for identifying and prioritizing management techniques.

There is an innate and irreplaceable value in in-field surveys; however, modern monitoring approaches will improve our ability to capture universal patterns of post-fire vegetation dynamics across urban riparian environments, as well as providing rapid assessments after fires. One metric that provides context for the biophysical disturbance of vegetation, as well as the socio-economic impact of a fire, is burn severity [16]. Two widely used indices to measure the effect of fire on biomass are the differenced normalized burn ratio (dNBR) and the differenced normalized difference vegetation index (dNDVI). Generally, both remote sensing indices are used to quantify the loss of biomass or organic matter with respect to the pre-fire conditions of an ecosystem. Almost all previous studies found that dNBR had the strongest relationship with in-field observations of burn severity [18]. However, the development of these metrics focused on the measurement and definition of burn severity within boreal forests and upland chaparral environments [18], while the effect of fire on riparian ecosystems is generally underrepresented $[4,19]$.

There is a need to understand the measurement and sensitivity of burn severity metrics in Mediterranean riparian areas, most notably in urban and wildland-urban interface (WUI) environments, which are capable of rapid biophysical changes under climate and anthropogenic influences. Developing quantitative assessments for to evaluate the effect of fire on diverse riverine habitats within urban areas will improve the management and mitigation of fire's impacts on human safety and ecosystems. We hypothesized that the presence of invasive vegetation species would alter the relationship between the upland, riparian, and invasive zones' burn severity and canopy loss. The main objectives of this study are to 1) measure and compare dNBR (burn severity) and dNDVI (canopy loss) between upland and riparian zones in urban environments, 2) determine if the presence of invasive vegetation species alters the relationship between the upland and riparian zones, burn severity, and canopy loss over time, and 3) determine if the current burn severity and canopy loss indices are valid within the urban Med-sys.

\section{Methods}

\subsection{Study Area}

Southern California has a semi-arid, Mediterranean climate, where a prolonged dry season from late spring to late fall is interrupted by a relatively short wet period from December to March [20]. The southern California Mediterranean type ecosystem (MTE) is characterized by chaparral shrub- and scrub-dominated hillslopes that feed into downslope temperate woodland riparian corridors. This study focuses on riparian areas of southern California that exist in or adjacent to the urban environment that are exhibiting ecological shifts towards vegetation cover dominated by non-native species. We also focus on one of 
the most prolific species, Arundo donax, in urban and WUI southern California drainages, and its role in the grass-fire cycle.

To represent a range of urban and Mediterranean vegetation and fire conditions, data from eleven fires were collected from the southern California region. Ten fires were selected from the California Department of Forestry and Fire Protection (CalFire) Fire and Resource Assessment Program (FRAP) 2018 database and one additional fire, estimated from satellite imagery, used as a case study (Figure 1). All fires selected have the following characteristics: occurred in southern California from 2007 to 2018, the burned area was less than $40 \mathrm{~km}^{2}$, included a river or creek [21] and therefore a measurable riparian corridor, and the fire was near or encompassed urban land-use [22]. Seven fires included invasive vegetation cover [14], and three control fires (Colina and West Fires) had no invasive cover (Table 1). The 2018 Del Cerro fire was a small urban fire that was incorporated as the eighth invasive fire, and the eleventh fire in total. In June 2018, the Del Cerro fire burned a substantial portion of the riparian zone along Alvarado Creek, a perennial and channelized tributary of the San Diego River in California. This human-ignited brush fire was fueled primarily by the presence of non-native and highly invasive Arundo donax and Washingtonia spp.

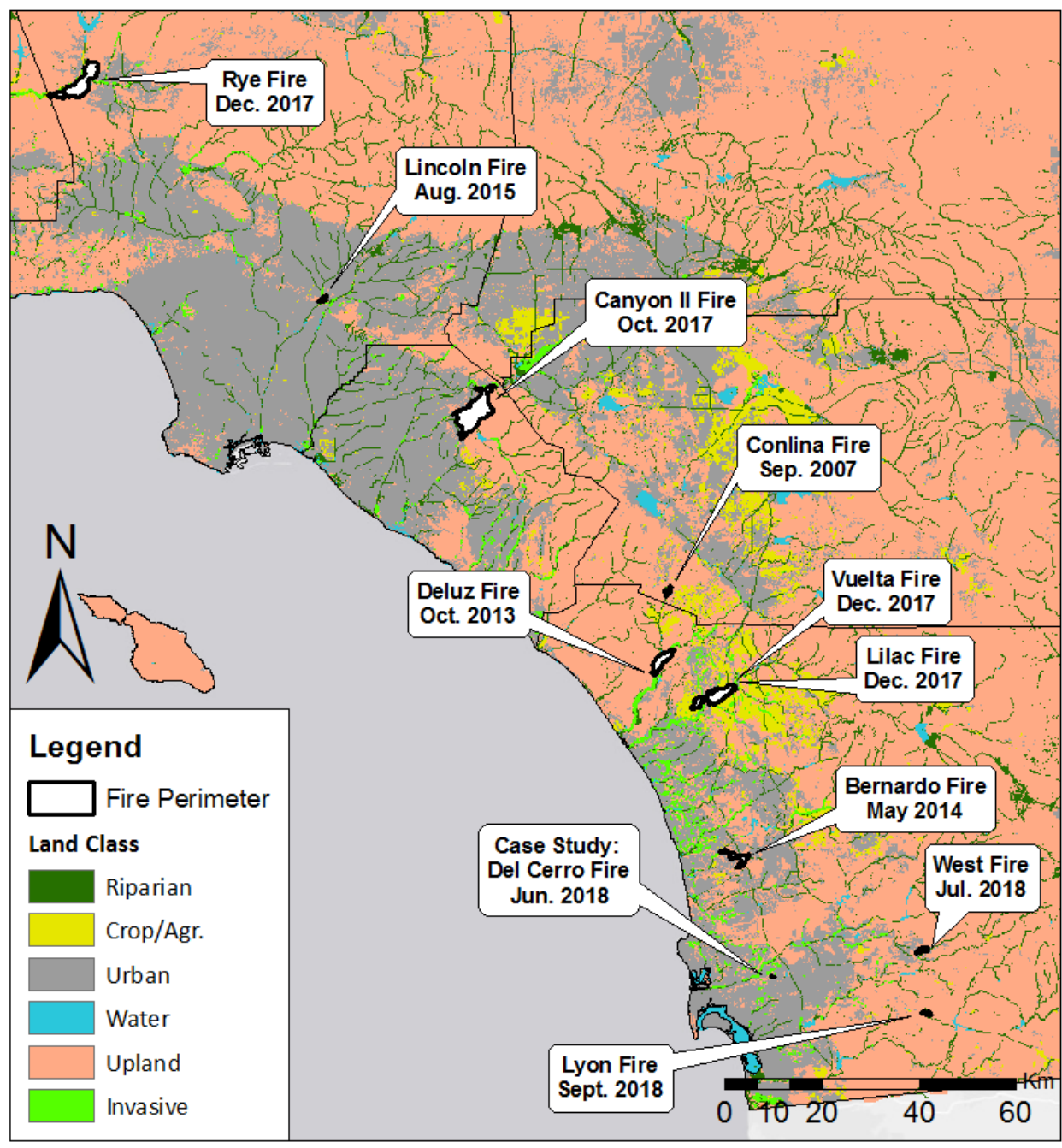

Figure 1. Eleven urban fires in southern California. The land class is shown at 30-m resolution within each county. 
Table 1. Characteristics for the eleven selected fires in order of ascending total acres burned. Note that only the percentages of invasive, riparian, and upland cover, which are relevant to this study, are reported.

\begin{tabular}{|c|c|c|c|c|c|c|c|c|c|}
\hline Name & $\begin{array}{c}\text { Ignition } \\
\text { Date }(\mathrm{m} / \mathrm{d} / \mathrm{y})\end{array}$ & $\begin{array}{l}\text { Containment } \\
\text { Date }(\mathrm{m} / \mathrm{d} / \mathrm{y})\end{array}$ & County & Impacted River & Ignition type & $\begin{array}{c}\text { Total Area } \\
\text { Burned } \\
\left(\mathbf{k m}^{2}\right)\end{array}$ & $\begin{array}{l}\text { Percent } \\
\text { Invasive } \\
\text { Cover }\end{array}$ & $\begin{array}{l}\text { Percent } \\
\text { Riparian } \\
\text { Cover }\end{array}$ & $\begin{array}{c}\text { Percent } \\
\text { Upland } \\
\text { Cover }\end{array}$ \\
\hline Del Cerro & $6 / 3 / 2018$ & $6 / 4 / 2018$ & San Diego & Alvarado Creek & Juveniles & 0.15 & $8.02 \%$ & $37.04 \%$ & $53.09 \%$ \\
\hline Colina Fire & $9 / 10 / 2007$ & $9 / 10 / 2007$ & Riverside & Deluz Creek & Vehicle Accident & 0.87 & $0.00 \%$ & $17.93 \%$ & $81.29 \%$ \\
\hline $\begin{array}{l}\text { Lincoln } \\
\text { Fire }\end{array}$ & $8 / 16 / 2015$ & Unknown & $\begin{array}{c}\text { Los } \\
\text { Angeles }\end{array}$ & Rio Hondo & Transient Camp & 0.95 & $14.23 \%$ & $41.17 \%$ & $37.25 \%$ \\
\hline Lyon Fire & $9 / 9 / 2013$ & $9 / 12 / 2013$ & San Diego & Wilson Creek & Accidental & 1.06 & $0.00 \%$ & $9.87 \%$ & $90.13 \%$ \\
\hline West & $7 / 6 / 2018$ & $7 / 10 / 2018$ & San Diego & Viejas Creek & Unknown & 2.04 & $0.00 \%$ & $17.65 \%$ & $33.98 \%$ \\
\hline Bernardo & $5 / 13 / 2014$ & $5 / 18 / 2014$ & San Diego & Lusardi Creek & $\begin{array}{c}\text { Sparks from power } \\
\text { equipment }\end{array}$ & 6.26 & $1.25 \%$ & $29.43 \%$ & $64.99 \%$ \\
\hline Vuelta Fire & $6 / 16 / 2007$ & $6 / 18 / 2007$ & San Diego & San Luis Rey River & $\begin{array}{l}\text { Unknown- transient } \\
\text { camp suspected }\end{array}$ & 9.02 & $37.64 \%$ & $58.01 \%$ & $4.03 \%$ \\
\hline Deluz Fire & $10 / 5 / 2013$ & $10 / 14 / 2013$ & San Diego & $\begin{array}{l}\text { Santa Margarita } \\
\text { River }\end{array}$ & Unknown & 9.05 & $4.85 \%$ & $15.73 \%$ & $76.91 \%$ \\
\hline Lilac Fire & $12 / 7 / 2017$ & $12 / 16 / 2017$ & San Diego & San Luis Rey River & Unknown & 16.5 & $6.23 \%$ & $12.19 \%$ & $30.25 \%$ \\
\hline Rye Fire & $12 / 5 / 2017$ & $12 / 13 / 2017$ & $\begin{array}{c}\text { Los } \\
\text { Angeles }\end{array}$ & Santa Clara & Unknown & 24.5 & $1.89 \%$ & $6.51 \%$ & $78.44 \%$ \\
\hline Canyon 2 & $10 / 9 / 2017$ & $10 / 17 / 2017$ & Orange & $\begin{array}{l}\text { Santa Anna River } \\
\text { and Santiago Creek }\end{array}$ & $\begin{array}{l}\text { Embers from } \\
\text { Canyon } 1 \text { Fire }\end{array}$ & 37.3 & $0.14 \%$ & $11.86 \%$ & $78.53 \%$ \\
\hline
\end{tabular}

\subsection{Vegetation Classification}

The CalFire FRAP, in cooperation with the California Department of Fish and Wildlife VegCamp program and USDA Forest Service Region 5 Remote Sensing Laboratory (RSL), compiled land cover data available for California into a single statewide data set. These data span from approximately 1990 to 2014. During this period, the most current, detailed, and consistent data were collected and compiled into the common classification scheme, the California Wildlife Habitat Relationships (CWHR) system. This vegetation dataset, FVEG [23], in coordination with the National Hydrology Dataset (NHD) [21] was used to classify land types relevant to this study, including: (1) riparian, (2) upland, (3) cropland, (4) urban, and (5) water.

Non-vegetated land covers "water" and "urban" were classified by fveg, but vegetationbased land cover, such as cropland, riparian and upland area, were not pre-defined. Thus, we used vegetated areas categorized into the fveg database by the specific Wildlife Habitat Relationship Name (WHRname), which represents major vegetative complexes at a scale sufficient to predict wildlife-habitat relationships. The following WHRnames were combined as "riparian" land cover from the fveg dataset: Valley foothill riparian, Fresh emergent wetland, Saline emergent wetland, Wet meadow, Desert wash, Desert riparian, Marsh, Estuarine, and Riverine. The riparian cover created from the fveg dataset was often not contiguous through urban corridors, so the NHD dataset was used to identify additional riparian environments.

From 2008 to 2010, Cal-IPC mapped Arundo donax and other invasive plant species at high resolution in all coastal watersheds in California from Monterey to San Diego [14]. These high-resolution data were generalized to include all invasive species, resampled at 30-m resolution to match the Landsat raster grid, and appended to the fveg classifications. In all eleven fire perimeters, invasive vegetation was located solely in the riparian region and classified independently from either riparian or upland classes within the burn perimeter (Table 1). The final six land classifications in this study included (1) riparian, (2) upland, (3) cropland (4) urban, (5) water, and (6) invasive plants (Figure 1). Cropland, urban, and water classifications were omitted from all calculations to reduce noise from non-vegetation features and land classes that were not present. 


\subsection{Burn Severity and Vegetation Metrics}

Differenced normalized burn ratio (dNBR) identifies areas that have changed in the amount of charred plant material and soil, while differenced normalized difference vegetation index (dNDVI) identifies the change in the presence or absence of green vegetation. Landsat data images were acquired and processed prior to calculating dNBR and dNDVI metrics at a 30-m resolution (Table 2). Collection 1 level 1 data from the Landsat 5 Thematic Mapper ${ }^{\mathrm{TM}}$ or the Landsat 8 Operational Land Imager (OLI) and Thermal Infrared Sensor (TIRS) image data were collected for each fire based on the date of ignition. The Landsat digital number $(\mathrm{DN})$ was converted into a top of atmosphere (TOA) reflectance or the amount of light reflected to the satellite. The calculation of TOA from DN corrects for atmospheric conditions and the position of the sun, which mitigates the effects of light scattering in the atmosphere and results in a reduced haze and less wavelength distortion [24]. Further atmospheric correction was not required as the images selected for this study contained minimal cloud cover (less than $5 \%$ cover) or other obstructions. Acquisition dates for each image are noted in Table 2.

Table 2. Landsat imagery dates for each time-point condition for each fire.

\begin{tabular}{ccccc}
\hline Fire Name & $\begin{array}{c}\text { Immediately } \\
\text { Pre-Fire (1) }\end{array}$ & $\begin{array}{c}\text { Immediately } \\
\text { Post-Fire (2) }\end{array}$ & $\begin{array}{c}\text { One-Year } \\
\text { Post-Fire (3) }\end{array}$ & $\begin{array}{c}\text { Three-Years } \\
\text { Post-Fire (4) }\end{array}$ \\
\hline Del Cerro & 16 May 2018 & 21 June 2018 & 19 June 2019 & N/A \\
\hline Colina & 25 July 2007 & 11 September 2007 & 27 July 2008 & 17 July 2010 \\
\hline Lincoln & 7 August 2015 & 10 October 2015 & 9 August 2016 & 15 August 2018 \\
\hline Lyon & 10 August 2013 & 27 September 2013 & 29 August 2014 & 3 September 2016 \\
\hline West & 21 June 2018 & 13 July 2018 & 8 June 2019 & N/A \\
\hline Bernardo & 19 May 2014 & 29 May 2014 & 12 May 2015 & 1 May 2017 \\
\hline Vuelta & 6 May 2007 & 25 June 2007 & 25 June 2008 May 2010 \\
\hline Deluz & 11 September 2013 & 14 November 2013 & 30 September 2014 & 2 September 2016 \\
\hline Lilac & 25 November 2017 & 27 December 2017 & 12 November 2018 & N/A \\
\hline Rye & 2 December 2017 & 4 February 2018 & 26 November 2018 & N/A \\
\hline Canyon 2 & 8 October 2017 & 24 October 2017 & 27 October 2018 & N/A \\
\hline
\end{tabular}

\subsection{Differenced Normalized Burn Ratio (dNBR)}

Normalized burn ratio (NBR) is an effective measure of burn severity in a variety of landscapes ranging from forest to chaparral [25]. This index can be related to the severity of a wildfire in the ecosystem by quantifying the transition from vegetated terrain to dry, ashy soil that is interspersed with blackened vegetation [26]. The NBR is calculated by using the relative difference in reflectance between the near infrared (NIR) and short-wave infrared (SWIR) (Equation (1)) from Landsat 5 TM or Landsat 8 OLI/TIRS. Equation (1) is based on the physical properties of vegetation, where green plant growth reflects NIR well, while dry, burned soil reflects highly in the SWIR $[24,26]$. NBR is the ratio of the difference in percent reflectance between the two spectra and ranges between -1 and 1 .

NBR was calculated for the pre-fire, immediately post-fire, and one-year post-fire conditions for each fire (Table 2). Immediate images measure the fire impact on the landscape, while NBR after one year serves as a metric for longer-term and indirect ecosystem effects of fire [25]. Differencing the pre-fire and either immediate or one-year post-fire NBR (Equation (2)) creates a measure of burn severity. High dNBR values indicate high severity burn damage, and negative to low values indicate low burn severity to increasing vegetation productivity. $\mathrm{dNBR}$ for each fire was calculated using the three Landsat dates to capture the two time-point conditions (Table 2). See Equations (1) and (2) below:

$$
\begin{gathered}
\mathrm{NBR}=(\mathrm{NIR}-\mathrm{SWIR}) *(\mathrm{NIR}+\mathrm{SWIR})^{-1}, \\
\mathrm{dNBR}=\mathrm{NBR}_{\text {Pre-fire }}-\mathrm{NBR}_{\text {Post-fire }} .
\end{gathered}
$$


Burn severity approximated by dNBR, relates the change in reflectance from pre-fire to postfire conditions to the surveyed ecological and socio-economic impact of the fire $[18,26,27]$. We utilized the burn severity levels established by Lutes et al. [18] and Key and Benson [26]: enhanced regrowth ( -500 to -101$)$, unburned ( -100 to 99$)$, low severity (100 to 269), moderate severity (270 to 659), and high severity (660 to 1300).

\subsection{Differenced Normalized Difference Vegetation Index (dNDVI)}

Plant health, NDVI, was estimated through the relationship of chlorophyll light absorption for photosynthesis in the red (Red) wavelength with high reflectance in the NIR [28] (Equation (3)). A lower NDVI represents bare soil to sparse vegetation (0.025-0.09) and a higher NDVI represents green vegetation $(\geq 0.25)$ [24]. The vegetation index was used to estimate the vegetation or biomass change before and after fire. This approach illuminates the spatial and ecological shifts in vegetation distribution within the sample fires and estimates vegetation health through "greenness" [29,30]. In forested environments, dNDVI has a weaker relationship with field-based measurements of burn severity than dNBR [26]. However, in Tran et al. [31], it was an effective measure of fire severity in riparian environments (Equation (4)). See Equations (3) and (4) below:

$$
\begin{aligned}
& \mathrm{NDVI}=(\mathrm{NIR}-\mathrm{Red}) *(\mathrm{NIR}+\mathrm{Red})^{-1}, \\
& \mathrm{dNDVI}=\mathrm{NDVI}_{\text {Pre-fire }}-\mathrm{NDVI}_{\text {Post-fire }} .
\end{aligned}
$$

Keeley and Keeley [32] showed that the total canopy cover for chaparral systems stabilizes three years after a fire. This study used the three years after a fire to represent a "stabilized" state of vegetation. To monitor both the immediate and longer-term post-fire vegetation trends, the dNDVI for each fire was calculated using pixel to pixel analysis between four Landsat dates (pre-fire, post-fire, one-year, three-years) to describe three time-point conditions (Table 2). Sparks et al. [33] related fire radiative energy density (FRED: $\mathrm{MJ} \cdot \mathrm{m}^{-2}$ ) and in-field measurements of percent canopy loss to remotely sensed dNDVI observations. Based on Sparks et al. [33], we categorized levels of canopy loss (approximated by dNDVI) as unburned (<0.005), low (0.005 to 0.049), moderate (0.05 to $0.199)$ and high $(>0.2)$.

\subsection{Statistical Analysis}

To compare between vegetation classifications and between fires with invasive vegetation and without, control fires, fires that did not contain invasive cover, were separated into "upland control" and "riparian control" vegetation areas or "classes." Non-control fires, referred to as "invasive fires" through the rest of this study, were separated into "invasive," "riparian," and "upland" vegetation classes. Satellite image indices, dNBR and dNDVI (burn severity and green canopy loss), were compared between time-point conditions (Table 2) by each land class for each control or invasive fire using average values derived from 30-m resolution Landsat data. The average vegetation class values of burn severity and green canopy loss by each fire were also averaged across all control or invasive fires.

To compare the burn severity and green canopy loss between upland and riparian zones in urban environments (objective 1), we tested the hypothesis that riparian and upland vegetation would be different for both burn severity and green canopy loss across all fires (hypothesis 1). To determine if the presence of invasive vegetation species alters the relationship between the upland and riparian burn severity and the canopy loss immediately and over time (objective 2), we hypothesized that riparian and upland burn severity and green canopy loss would remain different between each time-point, showing a disparity between recovery efficacies (hypothesis 2; see Table 2). It was also hypothesized that the invasive vegetation class would experience higher immediate burn severity and canopy loss than all other vegetation classes in both invasive and control fires (hypothesis 3 ). Lastly, to determine if the current burn severity and canopy loss indices are valid within the urban Med-sys (objective 3), it was hypothesized that the relationship between dNBR 
versus dNDVI would be linear for each vegetation classification of both invasive and control fires (hypothesis 4). It was also hypothesized that, for Med-sys, green canopy loss and burn severity may have a stronger linear relationship in the riparian class than the upland class for both invasive and control fires (hypothesis 5).

All hypotheses regarding burn severity and canopy loss within all vegetation classes (invasive, riparian, riparian control, upland, and upland control) and between each fire were compared using unpaired two-tailed $t$-tests in Matlab (Table 2). The null hypothesis for each test was that the two-population means were equal and rejected if the resulting $p$-values were less than 0.05 . Significant results are defined by $p$-values less than 0.05 .

\section{Results}

To quantify the unique impacts of fire and the vegetation recovery dynamics of differing vegetation classifications in the Mediterranean riverine landscape, we discretized the invasive, riparian, and upland regions of eleven southern California urban fires and tracked dNBR and dNDVI for the first three years after fire.

\subsection{Immediate Burn Severity and Canopy Loss by Fire}

The Del Cerro and Colina fires had the smallest fire areas $\left(0.15 \mathrm{~km}^{2}\right.$ and $\left.0.87 \mathrm{~km}^{2}\right)$, and the Canyon 2 and Rye fires had the largest areas $\left(37.3 \mathrm{~km}^{2}\right.$; Table 1$)$. The percent cover of both riparian and invasive classes was calculated for each fire (Table 1). The three control fires, Colina, Lyon, and West, had no Arundo cover, while invasive vegetation in the riparian ranged from $0.14 \%$ (Canyon 2 Fire) to $38 \%$ (Vuelta). The Vuelta, Lincoln, and Del Cerro fires had the highest invasive to riparian cover ratios $(0.65,0.51$, and 0.35 , respectively), while the Canyon 2 and Bernardo fires had the smallest ratios (0.01 and 0.04).

To test if the immediate (0-year) burn severity was different between all vegetation classes and between control and invasive fires, the dNDVI was averaged for the upland, riparian, and invasive classes immediately following each fire (Figure 2A). The three control fires only tested upland and riparian vegetation and showed that the burn severity for each vegetation class was statistically different. The average 0 -year burn severities for both the Lyon $(0.48 \pm 0.13)$ and West fires $(0.39 \pm 0.21)$ were moderate and were over two times higher than the low burn severity in Colina $(0.18 \pm 0.10)$. The riparian burn severities in the Lyon and West fires were $18 \%$ and $30 \%$ higher than in the upland vegetation, while the riparian burn severity was only $8.9 \%$ higher than the upland in the Colina fire.

In general, the riparian areas tended to have a higher burn severity than the upland regions across both invasive and control fires ( 9 of 11 fires; Figure 2A). The average 0-year burn severity across all eight fires that had invasive cover was generally classified as moderate $(\mathrm{dNBR}=0.289$; Figure $2 \mathrm{~A})$. The highest 0 -year burn severity averaged across all vegetation classes occurred after the Deluz fire $(0.65 \pm 0.21)$, and the lowest occurred after the Canyon 2 fire $(0.16 \pm 0.08)$. Upland burn severity was statistically different from invasive burn severity across seven of the eight fires (Canyon 2, Bernardo, Rye, Deluz, Lilac, Lincoln and Vuelta). Upland burn severity was also significantly different from riparian burn severity for seven fires (Canyon 2, Bernardo, Rye, Deluz, Del Cerro, Lincoln and Vuelta Fire). Four fires (Bernardo, Rye, Deluz and Vuelta Fire) had statistically different burn severities for invasive vegetation compared to native riparian and upland vegetation classifications.

To test if the immediate (0-year) green canopy loss was different between all vegetation classes and between control and invasive fires, dNDVI was averaged by upland, riparian, and invasive classes immediately following each fire (Figure 2B). For the control fires, the average 0 -year green canopy loss for the upland and riparian classes for both the Lyon and West fires was over 50\% higher than the riparian and upland classes in the Colina fire. Similar to burn severity, the 0-year riparian and upland canopy losses were significantly different for only the Lyon and West fires, where the riparian cover was $28 \%$ and $40 \%$ higher than the upland vegetation, respectively. In addition, the average green riparian canopy loss for the Lyon and West fires ( $0.277 \pm 0.100$ and $0.271 \pm 0.142$, respectively) was 
significantly higher than all the fires with non-native vegetation present, except for the Deluz fire $(0.285 \pm 0.142)$.

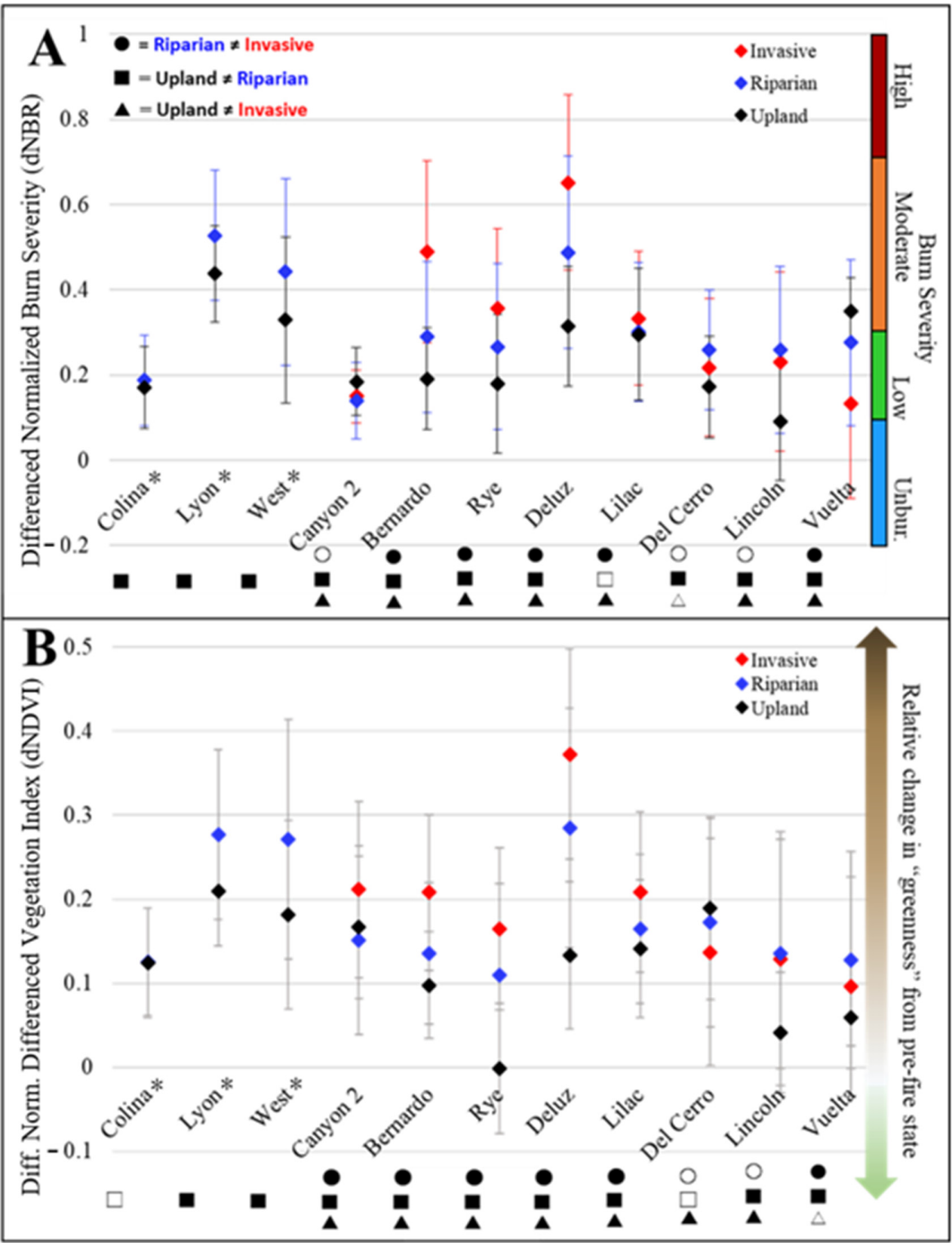

Figure 2. The dNBR and categorized burn severity by vegetation class immediately after each fire (A). The dNDVI and relative change in "greenness," by vegetation class immediately after each fire (B), where positive values above zero indicate a loss of greenness and negative values indicate an increase in greenness. Fires are in order of ascending percent invasive cover. The control fires have zero percent invasive cover and are denoted by * The results of the unpaired $t$-tests are denoted for each fire by shapes to represent each null hypothesis. If the null hypothesis was rejected, the results were statistically significant and symbolized by a solid shape. Statistically insignificant results are symbolized by open shapes.

We hypothesized that riparian green canopy loss in the dNDVI would be different from the upland class. This was true for nine of the eleven fires evaluated, including seven of the eight fires that burned invasive vegetation (Figure 2B). The average green canopy 
loss was significantly different between all vegetation classes for five out of the eight fires (Canyon 2, Bernardo, Rye, Deluz and Lilac). In the five fires that supported hypotheses $1-3$, the highest green canopy loss occurred in the invasive class where the canopy losses were, on average, $33 \%$ and $86 \%$ higher than the riparian and the upland areas, respectively. For six of the seven fires, the riparian vegetation class loss was, on average, $74 \%$ higher than the upland class, and was significantly different. The Canyon 2 fire was the only exception, where the upland and riparian burn severities were not significantly different, but the upland green canopy loss was $9.4 \%$ higher. The Del Cerro fire was the only case wherein the invasive region had significantly lower green canopy loss than the upland region. The highest 0 -year green canopy loss as the dNDVI averaged across all vegetation classes occurred after the Deluz fire $(0.263 \pm 0.118)$, and the lowest occurred during the Vuelta fire $(0.094 \pm 0.098)$.

\subsection{Average Burn Severity and Canopy Loss Patterns over Time}

To evaluate the patterns in burn severity between immediately after fire (0-year) and 1-year following fire, dNBR for each vegetation class was averaged across the eight invasive fires and three control fires (Figure 3A; Table 3). Across the eight fires with invasive vegetation, 0 -year burn severity was higher for invasive cover (moderate, $0.362 \pm 0.240$ ) compared to riparian (moderate, $0.254 \pm 0.193$ ) and upland cover (low severity, $0.205 \pm$ $0.134)$. This was statistically significant $(p<0.05)$. However, the average burn severity for the riparian vegetation in the control fires (moderate, $0.360 \pm 0.222$ ) was $35 \%$ higher than the burn severity observed in riparian areas of invasive fires. The riparian burn severity for control fires was similar to the burn severity of the invasive class for invasive fires, which was statistically significant at $p<0.05$.

Table 3. Mean dNBR and dNDVI values and standard deviations by vegetation class for each point in time. Control fire vegetation classes are denoted by *.

\begin{tabular}{cccccccc}
\hline & \multicolumn{2}{c}{ 0-Year Post-Fire } & \multicolumn{2}{c}{ 1-Year Post-Fire } & \multicolumn{2}{c}{ 3-Years Post-Fire } \\
\hline Veg. Class & dNBR & dNDVI & dNBR & dNDVI & dNBR & dNDVI \\
\hline Invasive & $0.362 \pm 0.240$ & $0.210 \pm 0.138$ & $0.211 \pm 0.181$ & $0.166 \pm 0.166$ & N/A & $0.029 \pm 0.090$ \\
\hline Riparian & $0.255 \pm 0.193$ & $0.161 \pm 0.121$ & $0.109 \pm 0.173$ & $0.203 \pm 0.134$ & N/A & $0.007 \pm 0.113$ \\
\hline Riparian * & $0.360 \pm 0.222$ & $0.218 \pm 0.134$ & $0.158 \pm 0.172$ & $0.057 \pm 0.088$ & N/A & $-0.041 \pm 0.093$ \\
\hline Upland & $0.205 \pm 0.135$ & $0.106 \pm 0.109$ & $0.035 \pm 0.119$ & $0.160 \pm 0.107$ & N/A & $0.015 \pm 0.107$ \\
\hline Upland * & $0.298 \pm 0.176$ & $0.167 \pm 0.087$ & $0.133 \pm 0.161$ & $0.057 \pm 0.082$ & N/A & $-0.033 \pm 0.085$ \\
\hline
\end{tabular}

The burn severity was statistically different between 0 - and 1-year for all classes, where 1-year burn severity was on average $63 \%$ lower than 0 -year. The largest percent change in burn severity between 0-year and 1-year occurred in the upland areas $(-83 \%)$, and the smallest percent change in burn severity occurred in the invasive class $(-42 \%)$. By 1 -year, the average burn severities for all vegetation classes were statistically different from 0 -year.

To compare the progressive change in green canopy loss following the fire, average dNDVI was evaluated as a proxy of "greenness" or green canopy loss for invasive and control fires by vegetation class for three points in time (Figure 3B). The highest average green canopy loss values occurred immediately following fire (0-year) and were recorded for riparian control and invasive classes $(0.360 \pm 0.222$ and $0.362 \pm 0.240$, respectively) The invasive and riparian controls were not statistically similar for 0 -year, however, all other classes were statistically different. This included the upland control $(0.167 \pm 0.087)$ and riparian class $(0.160 \pm 0.121)$, which were similar for 0 -year (Figure $3 \mathrm{~B})$. The upland class had the lowest immediate loss in the green canopy $(0.106 \pm 0.109)$ and was over $20 \%$ lower than all other vegetation classes. 


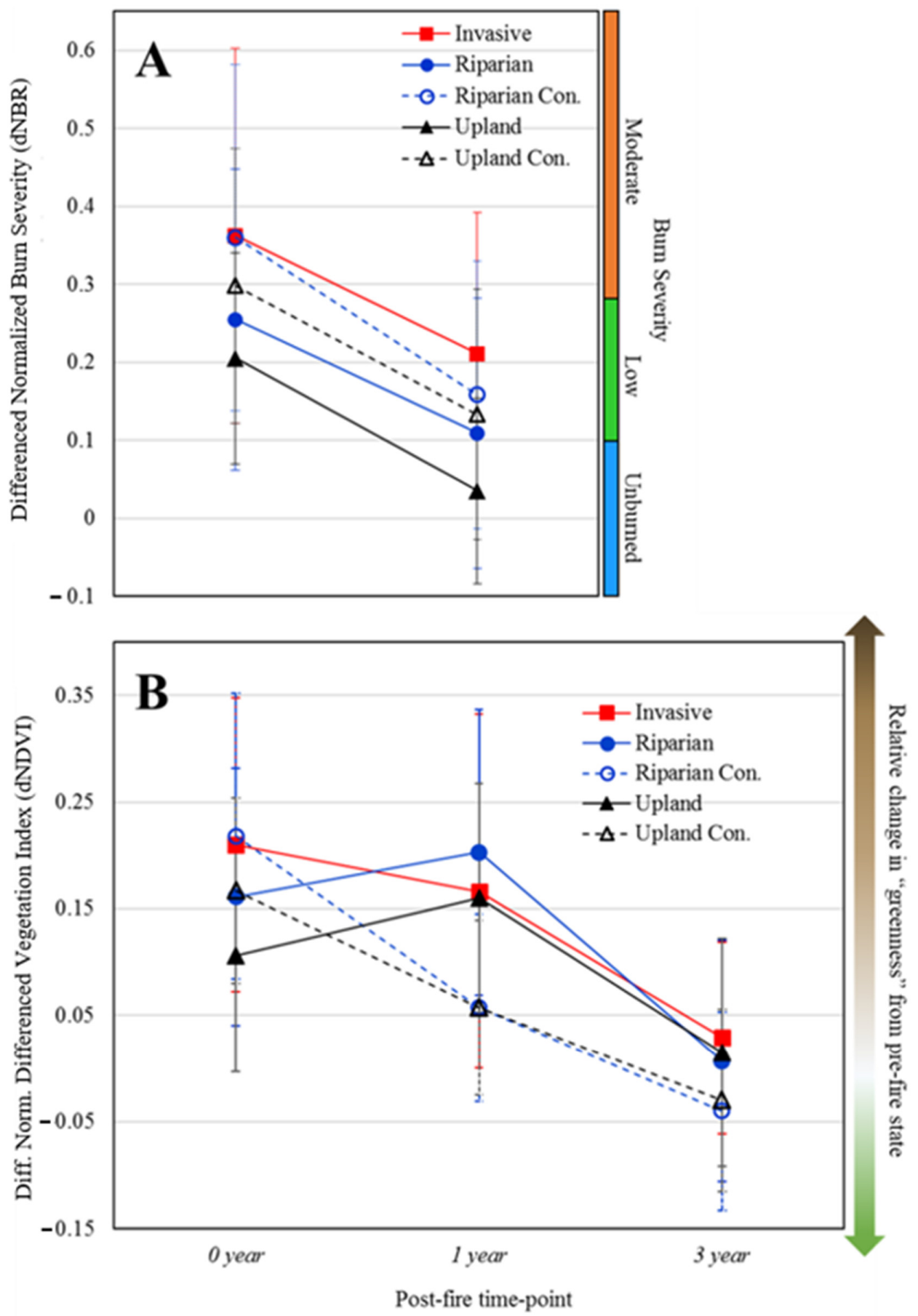

Figure 3. Average dNBR and burn severity across all fires by vegetation class for 0-year post-fire and 1-year post-fire (A). Burn severity is categorized by dNBR. Average dNDVI and relative change in "greenness" for invasive and control fires by vegetation class for 0 year post-fire, 1-year post-fire, and 3-year post-fire (B). Positive values above zero indicate a loss of greenness, and negative values indicate an increase in greenness.

One year following the fire, the largest green canopy recovery occurred for control fires, where the upland control class decreased by $-66 \%$, and the riparian control decreased by $-74 \%$. After 1-year, the average dNDVI for the upland and riparian classes in control fires converged and remained statistically similar to each other through the 3-year. The lowest recovery in green canopy 1-year post-fire occurred in the riparian class, where the 1 -year dNDVI value $(0.203 \pm 0.133)$ was $27 \%$ higher than the 0 -year value. The upland followed a similar pattern to the riparian but exhibited an even larger relative loss of green 
canopy with a 50\% increase in dNDVI (0.159 \pm 0.107$)$. Although an increase of green canopy was detected for the invasive class for the 1-year, it exhibited the smallest absolute change in dNDVI out of all the classes $(-21 \%)$. Further, the overall 1-year recovery of green canopy was over $20 \%$ higher in the invasive class $(0.166 \pm 0.165)$ than the riparian class and $4.3 \%$ higher than the upland class.

By 3-year, the green canopy loss generally diverged by control and non-control fires. The control upland and riparian classes increased in the green canopy by over $150 \%$ from 1-year to 3-year and by 3-year both had 18\% more green canopy cover than the pre-fire state. Conversely, the 3-year dNDVI for the riparian, upland, and invasive classes were positive, indicating less green canopy cover than the pre-fire state. The lowest green canopy recovery (dNDVI) by 3-year occurred in the invasive class $(0.028 \pm 0.089)$, followed by the upland and riparian classes, respectively $(0.015 \pm 0.106$ and $0.006 \pm 0.112)$. Although the 3-year values appeared similar, all classes were statistically different except for the riparian and upland control classes (Figure 4).

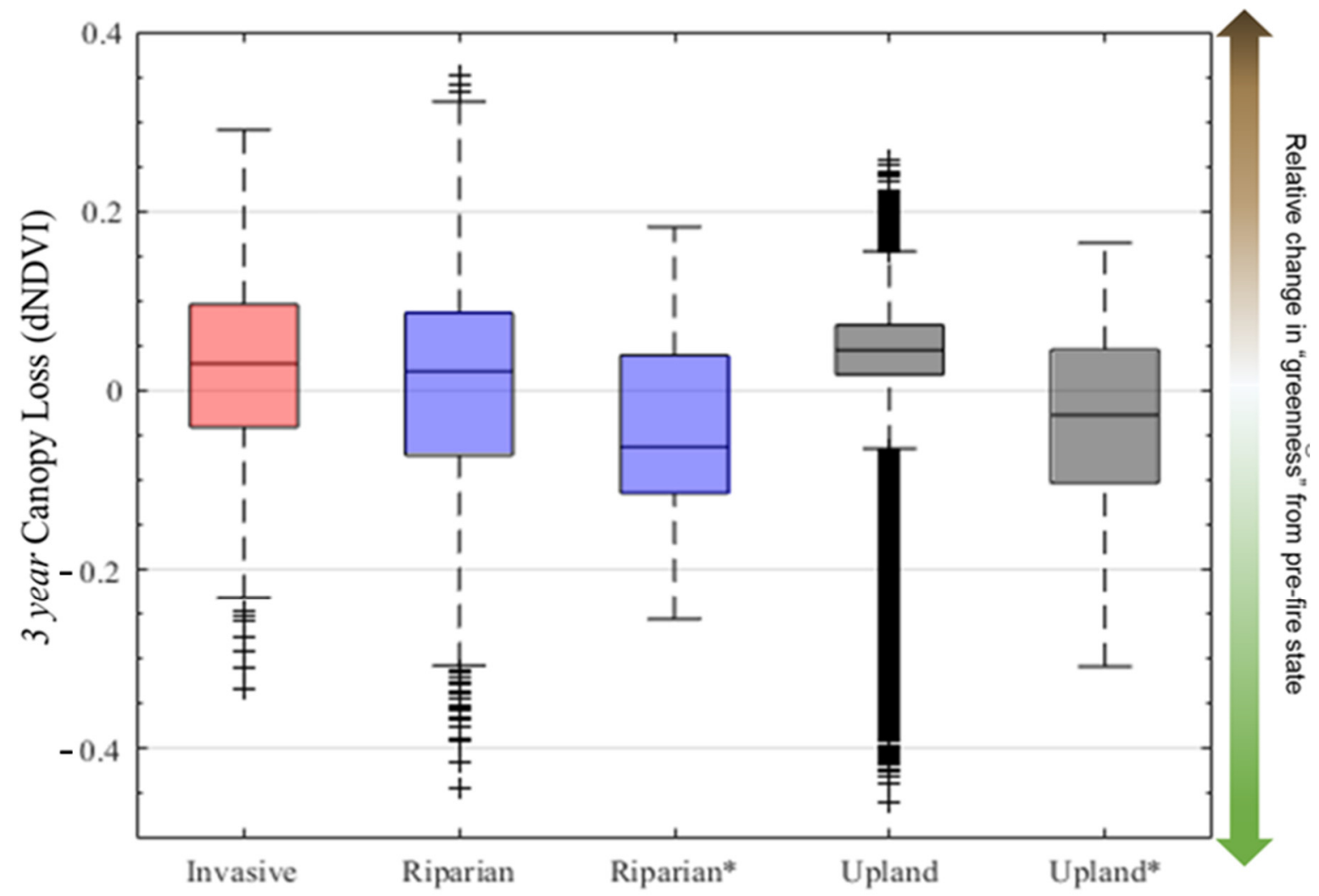

Figure 4. Canopy loss proxied by differenced Normalized Difference Vegetation Index (dNDVI) 3 years post-fire for each vegetation class. Control fire vegetation classes (no invasive species) are denoted by *. Box and whisker plots indicate the median, 25th, and 75th percentiles. The whiskers extend to the most extreme data points not considered outliers, and the outliers are denoted by ' + '.

\section{Discussion}

Dwire and Kauffman [4] noted that there is much to learn about riparian fire, and proposed interesting relations worth evaluating further, such as the compounded impacts of land-use change, invasive plant species, and other anthropogenic pressures on fire ecology and ecological recovery processes. It was recognized that senescence could impact estimates of burn severity and vegetation estimates. Traditionally, when vegetation indices are calculated using imagery from one year after the pre-fire date, it is assumed that error from seasonal senescence is removed due to the assumption that vegetation conditions are similar at the same time of year. Compared to woody annuals in upland environments, 
riparian perennials grow extremely quickly [34-36]. In particular, grasses and forbs sprout quickly after winter rains and desiccate by early summer [37]. As a result, there are significant seasonal changes in vegetation cover and health within a rapid time frame that may affect the accuracy of remotely sensed plant health and burn severity [38]. Based on an unpaired two-tailed $t$-test, the pre- and post-fire unburned riparian areas were statistically similar. In an auxiliary analysis, we confirmed that reflectance changes were not due to senescence in any of our eleven fires.

\subsection{Influence of Invasive Plants on Burn Severity and Green Canopy Loss after Fire}

Generally, across all the fires, including the control fires, the 0-year burn severity and green canopy loss was statistically different between the upland and riparian regions (hypothesis 1). This was reflected in the averaged results (Figure 3), where the riparian region experienced higher burn severity and canopy loss immediately following the fire, supporting previous observations by Dwire and Kauffman [4] and Petit and Naiman [17]. Contrary to hypothesis 3, invasive fires did not burn more severely or experience more canopy loss on average in the riparian and upland class than control fires (Figure 3). Instead, invasive fires experienced depressed burn severity and green canopy loss in the riparian and upland classes. However, the average severity and green canopy loss of the invasive class was as high as the control fires. In fact, when the trends of the vegetation indices of each class are examined by fire, it was only fires with low to moderate invasive cover (Table 1) that had the highest burn severity and green canopy loss within the invasive classification of vegetation (Figure 2). Although these trends were statistically significant, our results highlight that the large variability between each fire suggests the need for more field investigations that capture a range of environmental factors to further our understanding of the impact of invasive vegetation on fire behavior in urban Med-sys.

\subsection{Evidence of the Grass-Fire Cycle}

Hypothesis 2, the highest burn severity and green canopy loss would occur in fires with a higher percentage of highly invasive vegetation, was rejected for Del Cerro, Lincoln, and Vuelta (Table 1 and Figure 2). In accordance with grass-fire cycle theories, our results suggest that the type of vegetation growth forms that make up the fuel loads in the urban Med-sys strongly affect the severity of the fire and the corresponding vegetation loss. A high proportion of grass, herbaceous, and fan palm cover, which is typical in the urban Medsys, with extreme invasive cover preceding the fire $[9,10,15]$ contrasts with the abundance of woody fuels and deep green characteristics that are typical of chaparral and riparian tree species [39].

Low-severity fires within invasive grass stands were observed by Keeley [40]. This process favors the survival and propagation of alien vegetation species [40]. The homogenous grass and herbaceous cover found in Med-sys that are severely impacted by invasive species colonization generally have lower burn severity. This is due to the lower presence of woody biomass (fuel), which leads to quicker fire movement [41]. Riparian ecosystems with more complex vegetation communities and vertical fuel structures, such as the control fires and fires with low invasive cover (Canyon 2, Bernardo, Rye, and Deluz fires), may burn with a higher intensity and also have a more heterogeneous burn severity or green canopy loss pattern [25].

The most prominent invasive vegetation observed in all burn perimeters investigated was Arundo donax, a tall bamboo-like member of the grass family (Poaceae) commonly known as giant reed [11,42]. Arundo donax is widely associated with fire in the southern California Med-sys. It thrives and rapidly regrows in monocultures or stands following fire $[11,15,43]$. In addition to outcompeting native riparian species, Arundo donax can use three times more water resources, contributing to the aridification of Med-sys riparian communities [11,44]. The compounded effects of rapid regrowth, the aridification of riparian systems, and increased fuel loads following fire make Arundo donax an archetypal plant for grass-fire feedback. 
One year after fire, the results averaged over all invasive fires showed that only areas dominated with invasive vegetation (invasive class) saw canopy health recovery (Figure 3B). However, this is influenced by the four fires with the highest percentage of invasive cover (Lilac, Del Cerro, Lincoln, and Vuelta; Figure 5). In contrast, the four fires with the lowest percentage of invasive cover showed an even greater loss of canopy health immediately following the fire, which is similar to the trend exhibited by riparian and upland classes. These results support the grass-fire cycle hypothesis [45] and the promotion of secondary ecological impacts such as invasive vegetation infestations in riparian Med-sys ecosystems [17]. This effect, while already meriting consideration, could be exacerbated by climate change and anthropogenic activities. These disturbances could create favorable conditions for opportunistic invasive species. Since areas colonized by invasive species are more prone to wildfires, a self-perpetuating loop exists that selects for quickly regenerating invasive vegetation [46].

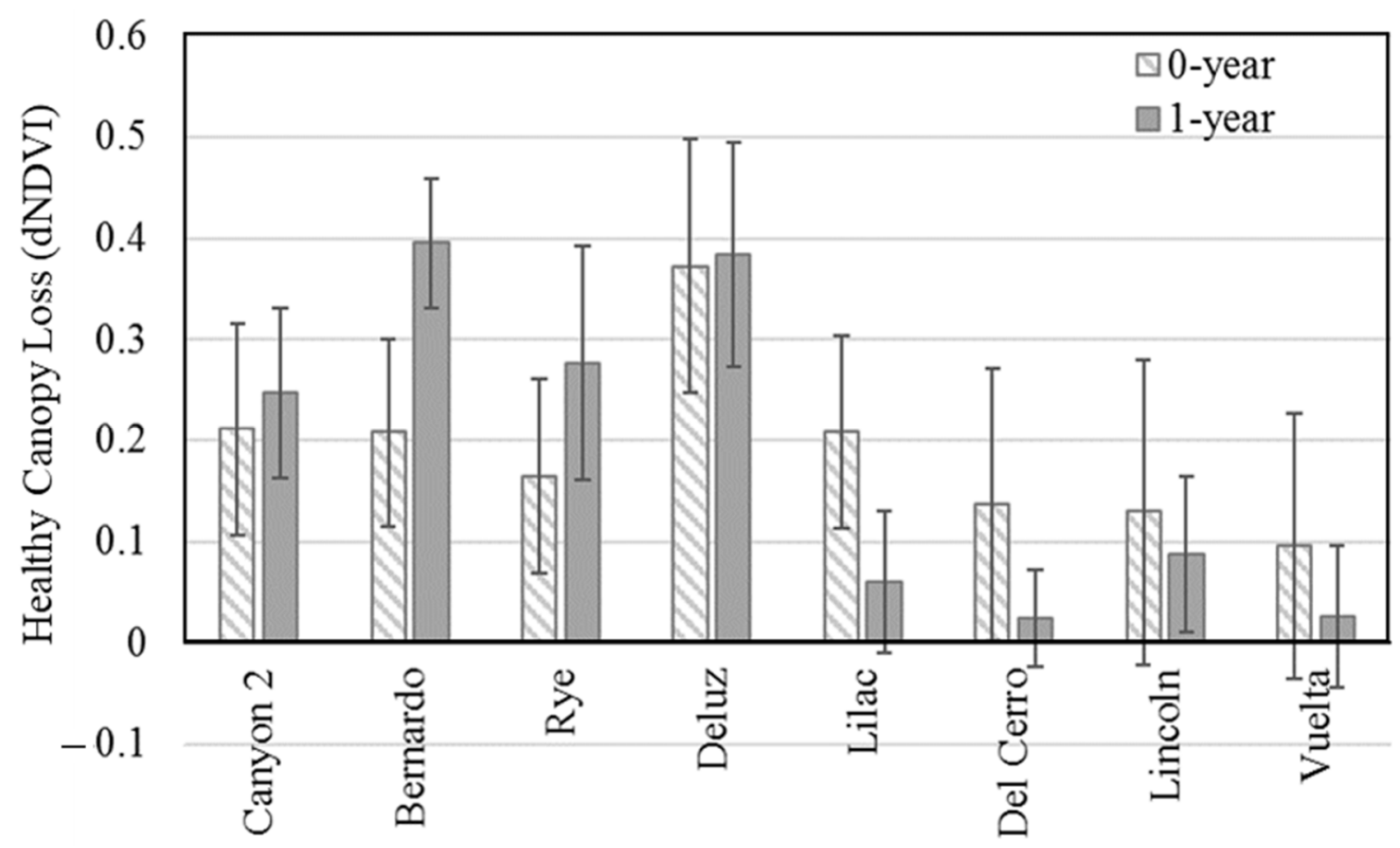

Figure 5. The comparison of green canopy loss (dNDVI) within the invasive class at 0-year and 1-year post-fire for each fire.

\subsection{Highlighting the Uncertainty of Burn Severity and Canopy Loss Metrics in Urban Riparian Environments}

Studies such as those by Key and Benson [26] and Tran et al. [31] showed that dNDVI may be more effective in identifying fire severity in woodland riparian environments, but less effective in chaparral-dominated ecosystems. When immediate (0-year) dNBR is compared against the corresponding dNDVI values, the relationship is almost linear across all vegetation classes and fires (Figure $6 \mathrm{~A}$ ). The $\mathrm{R}^{2}$ for the control fires is much greater than the $\mathrm{R}^{2}$ for the invasive fires ( 0.92 and 0.39 , respectively). However, the agreement between $\mathrm{dNBR}$ and dDNVI for invasive fires increased as burn severity increased. In other words, the highest $\mathrm{R}^{2}$ occurred for invasive fires that experienced both the greatest burn severity as well as canopy cover (Figure 6B). The agreement in dNBR and dNDVI for high-severity fires has been shown in previous work, such as Franco et al. [12]. 

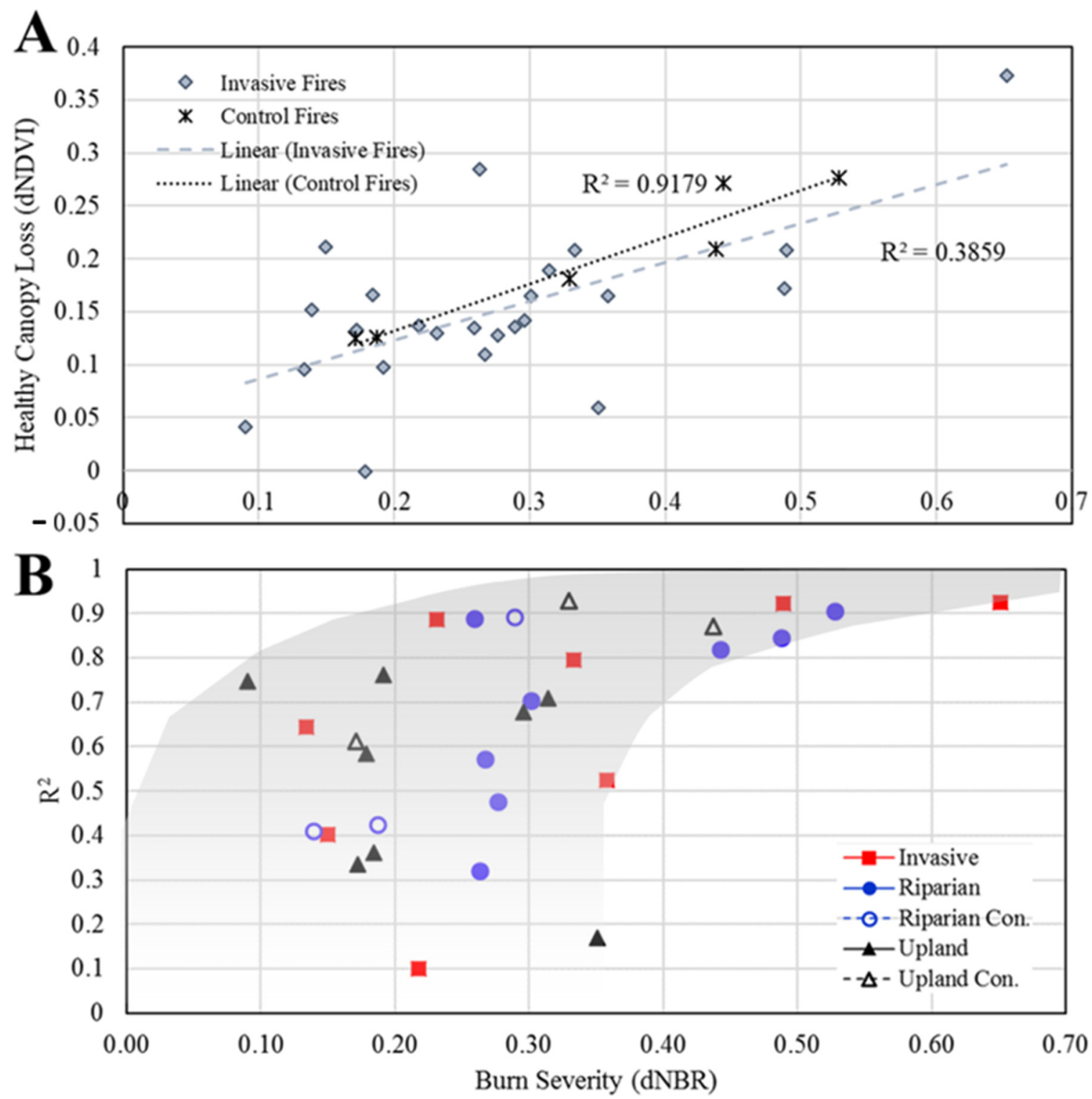

Figure 6. (A) The relation between average dNBR and dNDVI by class with respect to post-fire condition immediately after the fire (0-year). The regression equation and $R^{2}$ are denoted for invasive and control fires. (B) The average dNBR and $R^{2}$ by vegetation class with increasing burn severity. The grey shading highlights the approximate horizontal range of burn severity values.

Due to the aggressive nature of non-native vegetation, the rapid greening that occurs in the time between a wildfire and measurements (field-based or remote sensing) can often belie the true severity of a wildfire [15]. This is especially true in southern California, where both native and non-native forbs and grasses re-establish quickly after a wildfire [25] Some of these species grow at incredible rates, such as Arundo Donax, which can grow over $3 \mathrm{~cm}$ per day [15]. It is not always possible to obtain satellite images within such a narrow timeframe $[25,38]$. Thus, the metrics such as those used in this study are susceptible to large errors due to the growth patterns of invasive vegetation.

The remote sensing results revealed that the immediate burn severity (dNBR) in the riparian area was higher than in the upland area. We also noted that the immediate burn severity of the invasive vegetation was not statistically different from in the upland or riparian areas (Figure 3A). In contrast, the smallest immediate loss in the green canopy (dNDVI) occurred in the areas with invasive vegetation, and the greatest loss in canopy occurred in the upland (Figure 3B). The lowest green canopy cover (NDVI) detected 
immediately post-fire (0-year) occurred in the uplands, which was also the only region that reflected bare ground levels at any time-point measured following a fire $(0.19 \pm 0.09)$. These patterns are expected given the typical distribution of chaparral near urban areas $[2,3,46,47]$ compared to the denser canopy cover of riparian areas [4]. These results also highlight the general bias in dNDVI towards green new regrowth, such that the canopy loss signal is dampened in the riparian corridor dominated by invasive vegetation, despite the bare ground being exposed due to the fire.

The concentration of canopy loss on the upland slope nearest the riparian zone suggests that the riparian-upland interfaces in urban areas are vulnerable during and after urban fires. The combination of extra fuel loads, woody debris and abundant grasses accumulating in the riparian zone $[48,49]$, and the high flammability of chaparral vegetation due to volatile compounds $[6,25,47,50,51]$, may encourage intense and sustained fires that can severely impact vegetation health $[25,52]$. We encourage future field studies to confirm the remotely sensed spatial patterns observed in the ten urban fires we presented.

Overall, the discrepancy between dNDVI and dNBR immediately following fire is attributed to the rapid regeneration of non-native vegetation within the invasive and riparian regions and the inherent limitations of remote sensing metrics. We hypothesize that directly after the low-severity fire, the biomass and water content were low, but the greenness was higher as a result of the presence of small and new invasive grass shoots. Thus, the immediate post-fire measurement of dNDVI has a higher likelihood of underestimating the green canopy loss [53]. This is observed by the pattern found across all fires in our study (Figure 6), where the linearity between low-severity fires and green canopy loss deteriorated. Further, we observed that the accuracy of remotely sensed immediate canopy loss (dNDVI) in the urban Med-sys is highly reliant on the availability of observations less than a week following the fire. If satellite images are unavailable, metrics derived to guide management in post-fire areas should be avoided or used cautiously.

\section{Conclusions}

This research highlighted the different burn severity and green canopy loss patterns of riparian and upland regions in urban Mediterranean riverine systems across a spectrum of invasive vegetation cover, from zero to over 30\% invasive. In all fires observed, with or without invasive vegetation, the riparian class burned more severely and experienced a greater loss of green canopy than the upland class. However, the presence of invasive vegetation did affect the magnitude of burn severity and canopy loss within both the riparian and upland regions of burned Med-sys. On average, fires with no invasive cover (the control fires) burned at an overall higher severity and resulted in a higher immediate loss of green canopy in the upland and riparian areas than invasive fires. Some invasive fires (generally with low to moderate invasive vegetation cover) and control fires had the same magnitude of burn severity, except in different vegetation classes. In fires with low to moderate invasive cover, the burn severity was just as great as that recorded in the riparian area of control fires, but was concentrated in the invasive class. Fires with high invasive cover generally exhibited low burn severity across all vegetation classes (upland, riparian and invasive). These patterns of burn severity across the spectrum of invasive vegetation cover may indicate the current degree of disturbance each landscape has succumbed to within the grass-fire cycle. The low burn severity observed in already invaded landscapes favored the life cycle of opportunistic and invasive grasses, potentially perpetuating and promoting the spread of invasive cover across vegetation classes in urban riverine systems.

There are the significant implications of rapid vegetation regeneration for the accuracy of remote sensing techniques. Contrary to previous literature, satellite imagery of invasive fires did not capture a substantial increase in green canopy in the invasive or riparian regions after fire. However, our results suggest a need for more frequent imagery after the fire to capture the regrowth that occurs between the extinguish date of the fire and the first available image post-fire, especially in areas prone to aggressive non-native vegetation growth. Observations from the field documented the presence of invasive vegetation 
regrowth prior to the first available satellite image. This demonstrated that satellite-based techniques can miss the initial green canopy loss for rapidly re-sprouting and invasive grass species, such as Arundo donax, therefore underestimating the relative increase in green canopy. This study highlighted the role of invasive vegetation in urban fire regimes, and the need for improved monitoring strategies to accurately assess the initial biophysical impact of fire as well as the lasting ecological impacts in urban fluvial systems that are vulnerable to invasive vegetation infestation.

Author Contributions: L.E.H.M. and A.M.K. conceived and designed the work. L.E.H.M. acquired the data. L.E.H.M. analyzed and interpreted the data. L.E.H.M. and A.M.K. contributed substantial writing of the manuscript. All authors have read and agreed to the published version of the manuscript.

Funding: This material is based upon work supported by the National Science Foundation CAREER Program under Grant No. 1848577 and the California State University (CSU) CSU Council on Ocean Affairs, Science \& Technology (COAST) Rapid Response Funding Program Award \#COAST-RR-201704 and Graduate Student Research Award \#CSUCOAST-MATLAU-SDSU-AY1718.

Acknowledgments: This work was made possible by undying support of the SDSU Disturbance Hydrology Lab and excellent SDSU IT group. We also thank S. Zorn for his assistance.

Conflicts of Interest: The authors declare no conflict of interest.

\section{References}

1. Kinoshita, A.M.; Chin, A.; Simon, G.L.; Briles, C.; Hogue, T.S.; O’Dowd, A.P.; Gerlak, A.K.; Albornoz, A.U. Wildfire, water, and society: Toward integrative research in the "Anthropocene". Anthropocene 2016, 16, 16-27. [CrossRef]

2. Syphard, A.D.; Radeloff, V.C.; Keeley, J.E.; Hawbaker, T.J.; Clayton, M.K.; Stewart, S.I.; Hammer, R.B. Human Influence on California Fire Regimes. Ecol. Appl. 2007, 17, 1388-1402. [CrossRef] [PubMed]

3. Syphard, A.D.; Brennan, T.J.; Keeley, J.E. Drivers of chaparral type conversion to herbaceous vegetation in coastal Southern California. Divers. Distrib. 2019, 25, 90-101. [CrossRef]

4. Dwire, K.A.; Kauffman, J.B. Fire and riparian ecosystems in landscapes of the western USA. For. Ecol. Manag. 2003, 178, 61-74. [CrossRef]

5. Verkaik, I.; Rieradevall, M.; Cooper, S.D.; Melack, J.M.; Dudley, T.L.; Prat, N. Fire as a disturbance in mediterranean climate streams. Hydrobiologia 2013, 719, 353-382. [CrossRef]

6. Keeley, J.E.; Fotheringham, C.J. Historic Fire Regime in Southern California Shrublands. Conserv. Biol. 2001, 15, 1536-1548. [CrossRef]

7. White, M.D.; Greer, K.A. The effects of watershed urbanization on the stream hydrology and riparian vegetation of Los Peñasquitos Creek, California. Landsc. Urban Plan. 2006, 74, 125-138. [CrossRef]

8. D'Antonio, C.M. Fire, plant invasions, and global changes. In Invasive Species in a Changing World, 2nd ed.; Island Press: Washington, DC, USA, 2000; pp. 65-93. ISBN 78-1559637824.

9. Godefroid, S.; Koedam, N. Urban plant species patterns are highly driven by density and function of built-up areas. Landsc. Ecol. 2007, 22, 1227-1239. [CrossRef]

10. Aronson, M.F.; Lepczyk, C.A.; Evans, K.L.; Goddard, M.A.; Lerman, S.B.; MacIvor, J.S.; Nilon, C.H.; Vargo, T. Biodiversity in the city: Key challenges for urban green space management. Front. Ecol. Environ. 2017, 15, 189-196. [CrossRef]

11. Coffman, G.C. Factors Influencing Invasion of Giant Reed (Arundo donax) in Riparian Ecosystems of Mediterranean-Type Climate Regions. Ph.D. Thesis, University of California, Los Angeles, CA, USA, 2007.

12. Franco, M.G.; Mundo, I.A.; Veblen, T.T. Field-Validated Burn-Severity Mapping in North Patagonian Forests. Remote Sens. 2020, 12, 214. [CrossRef]

13. Collins, K.M.; Penman, T.D.; Price, O.F. Some Wildfire Ignition Causes Pose More Risk of Destroying Houses than Others. PLoS ONE 2016, 11, e0162083. [CrossRef] [PubMed]

14. Giessow, J.; Casanova, J.; Leclerc, R.; MacArthur, R.; Fleming, G. Arundo Donax (Giant Reed): Distribution and Impact Report; State Water Resources Control Board California Invasive Plant Council (Cal-IPC): Berkeley, CA, USA, 2011; pp. 1-240.

15. Coffman, G.C.; Ambrose, R.F.; Rundel, P.W. Wildfire promotes dominance of invasive giant reed (Arundo donax) in riparian ecosystems. Biol. Invasions 2010, 12, 2723-2734. [CrossRef]

16. Cushman, J.H.; Gaffney, K.A. Community-level consequences of invasion: Impacts of exotic clonal plants on riparian vegetation. Biol. Invasions 2010, 12, 2765-2776. [CrossRef]

17. Pettit, N.E.; Naiman, R.J. Fire in the Riparian Zone: Characteristics and Ecological Consequences. Ecosystems 2007, 10, 673-687. [CrossRef] 
18. Lutes, D.C.; Keane, R.E.; Caratti, J.F.; Key, C.H.; Benson, N.C.; Sutherland, S.; Gangi, L.J. FIREMON: Fire Effects Monitoring and Inventory System; RMRS-GTR-164; U.S. Department of Agriculture, Forest Service, Rocky Mountain Research Station: Ft. Collins, CO, USA, 2006.

19. Halofsky, J.E.; Hibbs, D.E. Controls on early post-fire woody plant colonization in riparian areas. For. Ecol. Manag. 2009, 258, 1350-1358. [CrossRef]

20. Swain, D.L.; Langenbrunner, B.; Neelin, J.D.; Hall, A. Increasing precipitation volatility in twenty-first-century California. Nat. Clim. Chang. 2018, 8, 427-433. [CrossRef]

21. US Geological Survey and US Department of Agriculture, Natural Resources Conservation Service. National Hydrography Dataset. Available online: https://www.usgs.gov/core-science-systems/ngp/national-hydrography/nhdplus-high-resolution (accessed on 1 January 2020).

22. California Department of Forestry and Fire Protection. Fire Perimeters Data. In Fire and Resources Assessment Program (FRAP); California Department of Forestry and Fire Protection's Fire and Resource Assessment Program (FRAP): Sacramento, CA, USA, 2018.

23. California Department of Forestry and Fire Protection. Vegetation (FVEG) Database. In Fire and Resources Assessment Program (FRAP); California Department of Forestry and Fire Protection's Fire and Resource Assessment Program (FRAP): Sacramento, CA, USA, 2015.

24. US Geological Survey. Landsat 8 (L8) Data Users Handbook. Available online: https:/ / prd-wret.s3.us-west-2.amazonaws.com/ assets/palladium/production/atoms/files/LSDS-1574_L8_Data_Users_Handbook-v5.0.pdf (accessed on 1 January 2020).

25. Lentile, L.B.; Morgan, P.; Hudak, A.T.; Bobbitt, M.J.; Lewis, S.A.; Smith, A.M.S.; Robichaud, P.R. Post-Fire Burn Severity and Vegetation Response Following Eight Large Wildfires Across the Western United States. Fire Ecol. 2007, 3, 91-108. [CrossRef]

26. Key, C.H.; Benson, N.C. Landscape Assessment (LA). In FIREMON: Fire Effects Monitoring and Inventory System; Lutes, D.C., Keane, R.E., Caratti, J.F., Key, C.H., Benson, N.C., Sutherland, S., Gangi, L.J., Eds.; General Technical Report RMRS-GTR-164-CD; U.S. Department of Agriculture, Forest Service, Rocky Mountain Research Station: Fort Collins, CO, USA, 2006; pp. LA-1-LA-55.

27. Keeley, J.E. Fire intensity, fire severity and burn severity: A brief review and suggested usage. Int. J. Wildland Fire 2009, 18, 116. [CrossRef]

28. Tucker, C.J. Red and photographic infrared linear combinations for monitoring vegetation. Remote Sens. Environ. 1979, 8, 127-150. [CrossRef]

29. Gamon, J.A.; Field, C.B.; Goulden, M.L.; Griffin, K.L.; Hartley, A.E.; Joel, G.; Peñuelas, J.; Valentini, R. Relationships Between NDVI, Canopy Structure, and Photosynthesis in Three Californian Vegetation Types. Ecol. Appl. 1995, 5, 28-41. [CrossRef]

30. Hope, A.; Tague, C.; Clark, R. Characterizing post-fire vegetation recovery of California chaparral using TM/ETM+ time-series data. Int. J. Remote Sens. 2007, 28, 1339-1354. [CrossRef]

31. Tran, B.N.; Tanase, M.A.; Bennett, L.T.; Aponte, C. Evaluation of Spectral Indices for Assessing Fire Severity in Australian Temperate Forests. Remote Sens. 2018, 10, 1680. [CrossRef]

32. Keeley, J.E.; Keeley, S.C. Post-Fire Regeneration of Southern California Chaparral. Am. J. Bot. 1981, 68, 524-530. [CrossRef]

33. Sparks, A.M.; Kolden, C.A.; Talhelm, A.F.; Smith, A.M.S.; Apostol, K.G.; Johnson, D.M.; Boschetti, L. Spectral Indices Accurately Quantify Changes in Seedling Physiology Following Fire: Towards Mechanistic Assessments of Post-Fire Carbon Cycling. Remote Sens. 2016, 8, 572. [CrossRef]

34. Holstein, G. Deciduous Islands in an Evergreen Sea. In California Riparian Forests: Ecology, Conservation and Productive Management; University of California Press: Berkeley, CA, USA, 1984.

35. Davis, F.W.; Keller, E.A.; Parikh, A.; Florsheim, J. Recovery of the Chaparral Riparian Zone After Wildfire. In Proceedings of the California Riparian Systems Conference: Protection, Management, and Restoration for the 1990s, Davis, CA, USA, 22-24 September 1988; Gen. Tech. Rep. PSW-GTR-110. Pacific Southwest Forest and Range Experiment Station, Forest Service, U.S. Department of Agriculture: Berkeley, CA, USA, 1989; pp. 194-203.

36. Bendix, J.; Cowell, C.M. Impacts of Wildfire on the Composition and Structure of Riparian Forests in Southern California. Ecosystems 2010, 13, 99-107. [CrossRef]

37. Minnich, R.A. Fire Mosaics in Southern California and Northern Baja California. Science 1983, 219, 1287-1294. [CrossRef] [PubMed]

38. Veraverbeke, S.; Lhermitte, S.; Verstraeten, W.W.; Goossens, R. The temporal dimension of differenced Normalized Burn Ratio (dNBR) fire/burn severity studies: The case of the large 2007 Peloponnese wildfires in Greece. Remote Sens. Environ. 2010, 114, 2548-2563. [CrossRef]

39. Park, I.W.; Hooper, J.; Flegal, J.M.; Jenerette, G.D. Impacts of climate, disturbance and topography on distribution of herbaceous cover in Southern California chaparral: Insights from a remote-sensing method. Divers. Distrib. 2018, 24, 497-508. [CrossRef]

40. Keeley, J.E. Fire Management Impacts on Invasive Plants in the Western United States. Conserv. Biol. 2006, 20, 375-384. [CrossRef]

41. Bowman, D.M.J.S.; MacDermott, H.J.; Nichols, S.C.; Murphy, B.P. A grass-fire cycle eliminates an obligate-seeding tree in a tropical savanna. Ecol. Evol. 2014, 4, 4185-4194. [CrossRef]

42. Perdue, R.E. Arundo donax-Source of musical reeds and industrial cellulose. Econ. Bot. 1958, 12, 368-404. [CrossRef]

43. Bell, G.P. Ecology and Management of Arundo donax, and Approaches to Riparian Habitat Restoration in Southern California. Available online: https:/ / ic.arc.losrios.edu/ \{\}veiszep/05spr2001/stelmok/g26files/attach5.html (accessed on 13 May 2020). 
44. Iverson, M.E.; Jackson, N.E.; Frandsen, P.; Douthit, S. The impact of Arundo donax on water resources. In Arundo Donax Workshop Proceedings, California Exotic Pest Plant Council, Riverside; Jackson, N.E., Frandsen, P., Duthoit, S., Eds.; Team Arundo Riverside: Ontario, CA, USA, 1994; pp. 19-26.

45. D'Antonio, C.M.; Vitousek, P.M. Biological Invasions by Exotic Grasses, the Grass/Fire Cycle, and Global Change. Annu. Rev. Ecol. Syst. 1992, 23, 63-87. [CrossRef]

46. Keeley, J.E.; Baer-Keeley, M.; Fotheringham, C.J. Alien Plant Dynamics Following Fire in Mediterranean-Climate California Shrublands. Ecol. Appl. 2005, 15, 2109-2125. [CrossRef]

47. Keeley, J.E. Chaparral. In North American Terrestrial Vegetation; Cambridge University Press: Cambridge, UK, 2000 ; pp. $203-254$.

48. Keeley, J.E.; Brennan, T.; Pfaff, A.H. Fire severity and ecosytem responses following crown fires in California shrublands. Ecol. Appl. 2008, 18, 1530-1546. [CrossRef]

49. Kobziar, L.N.; McBride, J.R. Wildfire burn patterns and riparian vegetation response along two northern Sierra Nevada streams. For. Ecol. Manag. 2006, 222, 254-265. [CrossRef]

50. Park, I.W.; Jenerette, G.D. Causes and feedbacks to widespread grass invasion into chaparral shrub dominated landscapes. Landsc. Ecol. 2019, 34, 459-471. [CrossRef]

51. Barro, S.C.; Conard, S.G. Fire effects on California chaparral systems: An overview. Environ. Int. 1991, 17, 135-149. [CrossRef]

52. Coppoletta, M.; Merriam, K.E.; Collins, B.M. Post-fire vegetation and fuel development influences fire severity patterns in reburns. Ecol. Appl. 2016, 26, 686-699. [CrossRef]

53. Morgan, P.; Keane, R.E.; Dillon, G.K.; Jain, T.B.; Hudak, A.T.; Karau, E.C.; Sikkink, P.G.; Holden, Z.A.; Strand, E.K. Challenges of assessing fire and burn severity using field measures, remote sensing and modelling. Int. J. Wildland Fire 2014, 23, 1045. [CrossRef] 